\title{
The Resilience of Small-Scale Fishing Households to the Anthropogenic Environmental Shocks
}

\author{
Le Thi Hong Phuong, ${ }^{1, *}$, Truong Quang Dung², Duong Ngoc Phuoc ${ }^{1}$, Le Thi Thanh Thuy ${ }^{1}$, \\ Tran Cao Uy ${ }^{1}$, Truong Van Tuyen ${ }^{1}$ \\ ${ }^{1}$ University of Agriculture and Forestry, Hue University, Vietnam \\ ${ }^{2}$ Hue College of Economics, Hue University, Vietnam \\ *Corresponding Author: 1thphuongnl@hueuni.edu.vn, lethihongphuong@huaf.edu.vn
}

Received August 27, 2021; Revised November 8, 2021; Accepted December 13, 2021

\section{Cite This Paper in the following Citation Styles}

(a): [1] Le Thi Hong Phuong, Truong Quang Dung, Duong Ngoc Phuoc, Le Thi Thanh Thuy, Tran Cao Uy, Truong Van Tuyen, "The Resilience of Small-Scale Fishing Households to the Anthropogenic Environmental Shocks," Environment and Ecology Research, Vol. 9, No. 6, pp. 389 - 398, 2021. DOI: 10.13189/eer.2021.090606.

(b): Le Thi Hong Phuong, Truong Quang Dung, Duong Ngoc Phuoc, Le Thi Thanh Thuy, Tran Cao Uy, Truong Van Tuyen (2021). The Resilience of Small-Scale Fishing Households to the Anthropogenic Environmental Shocks. Environment and Ecology Research, 9(6), 389 - 398. DOI: 10.13189/eer.2021.090606.

Copyright $(\mathrm{C} 2021$ by authors, all rights reserved. Authors agree that this article remains permanently open access under the terms of the Creative Commons Attribution License 4.0 International License

\begin{abstract}
The marine environmental incident causing mass fish death in Central Vietnam by Formosa Ha Tinh Steel Plant in 2016 severely impacted people's livelihoods in four provinces. Several previous studies have indicated that diversifying livelihoods is one of the best solutions to increase the resilience of households to overcome such incidents. This study investigated the relationship between livelihood diversification and the stability of small-scale fishing households. Our findings showed that impact levels and resilience capacity under family perception are important aspects for impact assessment in the context of the environmental shock. Local families can diversify their livelihoods based on their resources as well as through government-supporting policies. The livelihood diversification of impacted households is significantly valuable in increasing the resilience process after the Formosa incident. Families with more livelihood activities related to income sources have better resilience than families with less livelihood activities. By the effort of households and government support policies, impacted households have gradually improved their livelihood resilience.
\end{abstract}

Keywords Livelihood Diversification, Resilience, Small-Scale Fishing, Formosa, Vietnam

\section{Introduction}

The anthropogenic environmental shocks have critically affected vulnerable households, mainly those dependent on natural resources in many parts of the world $[1,2]$. Recently, a marine environmental incident (called the Formosa incident) caused by Formosa Ha Tinh Steel Corporation in central Vietnam and detected on April 6th, 2016, was an example of how an environmental shock impacted the lives of coastal communities. The Vietnamese government has announced that the Formosa incident was "the most serious environmental disaster Vietnam has ever faced" [3]. The illegal discharge of toxic waste emitted during trial operation of the newly built steel factory's wastewater discharge system had caused mass fish death along the Central Coast of Vietnam [5, 43, 44]. The release of wastewater containing phenol, cyanide, and iron hydroxides formed a colloidal iron complex (Mixel) and killed the aquatic population exposed to particularly bottom fish [4]. The total killed fish was estimated at over 300 tons, including wild fish (115 tons), farmed fish (100 tons), and clams (67 tons). These figures did not account for the loss of shrimp, cuttlefish, squid, and other aquatic species.

Consequently, the livelihoods of millions of people in four provinces in Central Viet Nam, including Ha Tinh, Quang Binh, Quang Tri, and Thua Thien Hue, have been significantly hit by the incident. Near-shore fishing boats 
were almost entirely inactive, and the supply chains for offshore aquatic products collapsed. Furthermore, related services such as processing, transportation, and marine tourism were completely suspended [3]. Although the company has claimed its responsibility and agreed to pay a compensation of nearly 500 million USD [45], it is undoubted that impacted communities have been facing considerable challenges to recover. The possibility for local people to successfully recover or adjust livelihoods and fully bounce back from this incident remains unclear. Thus, there is a pressing need for research to raise public awareness on the consequences of this anthropogenic environmental incident, build an understanding of the resilience of indigenous fishery communities to this kind of shock, and recommend appropriate policies.

Resilience has been rapidly becoming a key concept in research on human-nature interactions. The idea is at the core of exploring how individuals and households cope with climatic, economic, and social dynamics [22]. Carter et al. [1] defined resilience as the capacity to maintain a system's functions when environment is disturbed. The concept reflects the extent to which a complex system (e.g., a community) adapts to and re-organizes itself [10]. It is essential to understand the impacts of anthropogenic environmental incidents on local livelihood and its drivers to improve the resilience of rural households and communities.

Many studies acknowledge livelihood diversification as an effective strategy to cope with environmental and anthropogenic shocks in developing countries [11]. This strategy has received much attention for its essential role in the resilience of rural communities, especially when handling environmental turbulence. Livelihood diversification is defined as attempts by households to find new means of living to increase incomes, mitigate life pressures, and manage livelihood risks [12,13]. Livelihood diversification is also viewed as different strategies of using goods and assets of households to reduce vulnerability to changes and increase households' adaptation to different pressures to survive [14]. The diversification encompasses both on- and off-farm activities undertaken to generate additional income other than the main existing household agricultural activities. Specifically, diversifying households' livelihoods might include producing other farm goods, participating in a waged labor force, or starting a new business $[13,15,16]$. Rural livelihood diversification is commonly classified by sector (farm or non-farm), function (wage employment or self-employment), or location (on-farm or off-farm) [17, 18]. The motivation of livelihood diversification is driven by location, assets, income, opportunity, and social relations of households. Thus, outcomes might be significantly different according to household circumstances [19]. For instance, Elin Torell indicated that livelihood diversification had increased the income sources of poor households in Tanzania. Additionally, Ayeb-Karlsson, van der Geest [24] revealed that rural households in Bangladesh adopted two to three livelihood activities to reduce damages from stresses and shocks.

Livelihood diversification is common in coastal communities when households face undesired environmental changes [1, 15, 27, 28]. Besides traditional fishery livelihoods, local people often conduct farming or aquaculture when the weather does not support fishing. They also participate in the non-farm job sector by driving taxis or providing cleaning services.

The Vietnam fishery sector is feeding approximately 20 million people, directly and indirectly, involved in catching and trading fishery products [40]. Over the past ten years, the sector has developed substantially regarding the number of workers, fishing boats/vessels, and catches [41]. However, the poverty of fishing households, especially in the coastal communes (called "bai ngang" - with no harbor to park large boats), is severe when local people still strongly depend on the income from vulnerable fishing jobs. These communes are classified as "especially difficult communes" by the government. The World Bank (2014) estimated that the number of poor people in fishing communities is about 5.1 million, accounting for $30 \%$ of the total number of poor people in the whole country. Reasons include a significant decline in natural resources, climate change, and globalization [42].

In this paper, we investigate the possible correlation between the livelihood diversification of small-scale fishing households and their resilience to a livelihood shock. Livelihood diversification herein implies a process to generate additional income besides pure fishery activities. Using the Formosa incident as a case study, we try to understand the impacts of such an environmental disaster on indigenous fishery communities and how diversification strategies might help mitigate adverse effects.

\section{Methods}

\subsection{Study Sites and Sampling}

The study was carried out in 4 provinces in Central Vietnam, including Ha Tinh, Quang Binh, Quang Tri, and Thua Thien Hue (figure 1). They are areas where are most severely impacted by the Formosa incident. The selection of studied fishing communities was conducted by an in-depth interview with heads of each province's Department of Nature and Resource Environment (DONRE). Criteria for selections were: (1) the populations of fishery communities and (2) the severity of the incident's impacts. These data were calculated based on the households who received the compensation and support from the government [48].

In this study, four communes were selected: Ky Khang commune in Ha Tinh province; Phu Thuan commune in Thua Thien Hue province; Ngu Thuy Bac commune in Quang Binh province, and Hai An commune in Quang Tri 
province (figure 1). The number of impacted households by the Formosa incident in four selected communes was reported at 3,614, accounting for $48.5 \%$ of the total population in these communes [48].

This study's sample size was based on Slovin 1984 $(\mathrm{n}=\mathrm{N} / 1+\mathrm{Ne} 2)$, in which $\mathrm{n}$ is the sample size, $\mathrm{N}$ is the study population, e is sampling error. The formulas gave the result of 301 small-scale fishing households, representing approximately 14 percent of households whose livelihoods were impacted by the toxic leak in each commune, that were selected and interviewed using a semi-structural questionnaire.

\subsection{Data Collection}

Data collection started with a rapid rural appraisal to understand the significant social and physical features of the selected communes [50]. Secondary data was collected from authority documents about socio-economic impacts and compensations to understand the overall picture of the study areas since the occurrence of the incident.

Regarding primary data, to ensure appropriate case study selection, we conducted 44 in-depth interviews with heads of DONRE at four provinces and key informant interviews to understand in greater detail how the 'Formosa incident' impacted their lives and communities and how local people responded to the shock. Then, a household survey $(n=301)$ was conducted from August to December 2018, in which an interview took around 45 minutes to one hour. The surveyed households gave full consent when participating in the interviews. Collected data encompassed

(1) household demographic characteristics (size, number of labors, ethnicity, income, qualifications, etc.);

(2) impacts of the marine environment incidence 2016 on livelihoods which included: the occurrence of the marine environment incidence and changes caused by the incident in household livelihoods; and

(3) response, adaptation, and transformation adopted by the impacted households.

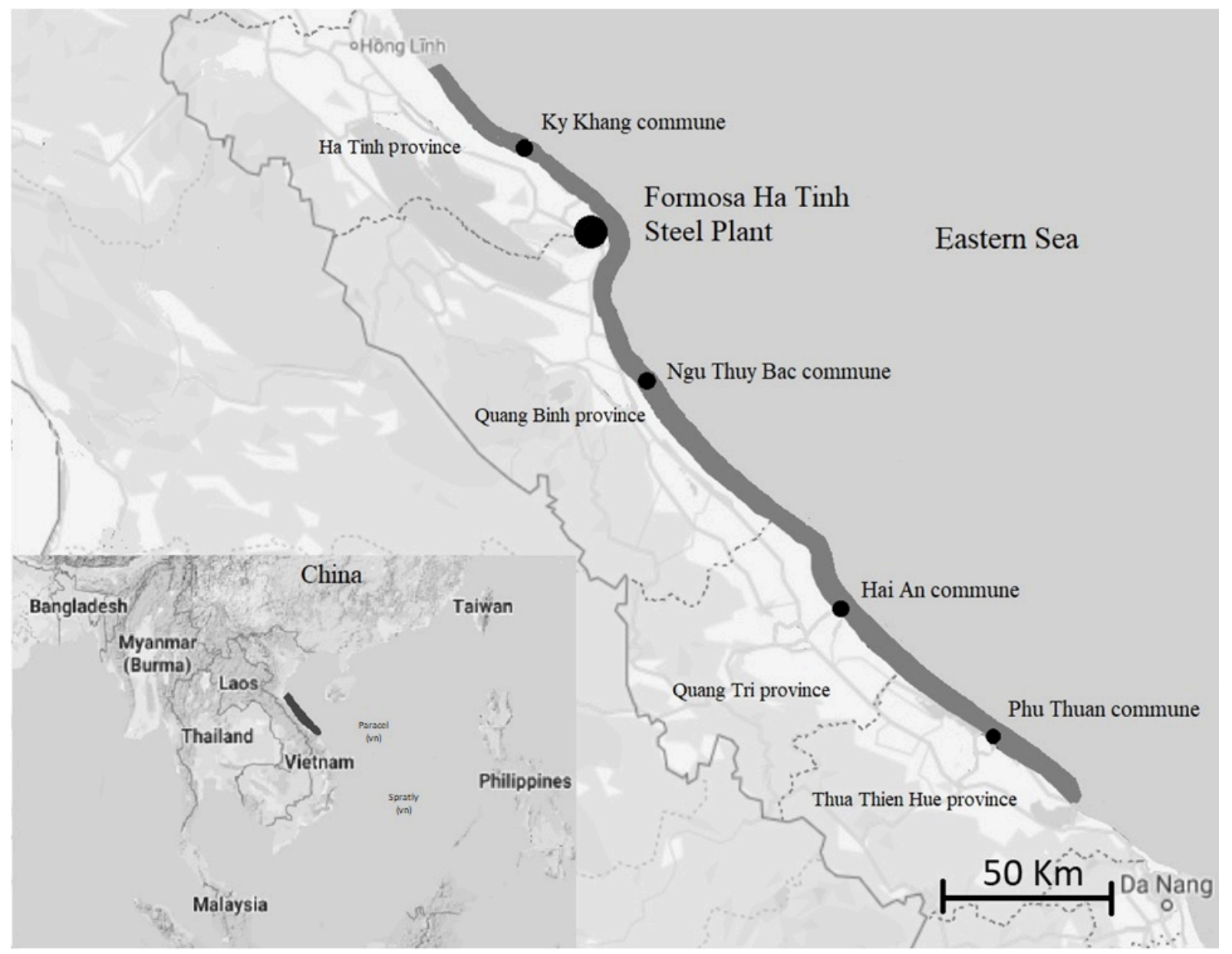

Figure 1. Map of study area impacted by the toxic chemical spill. Source: Google maps [47]. 


\subsection{Data Analysis}

Gathered data were categorized into four groups based on the diversification of participant's livelihoods, which are:

- Group I: 'fishing only' consisted of households whose livelihoods were solely dependent on fishing activities

- Group II: 'fishing \& services' consisted of households who traded fishery equipment and besides the fishing,

- Group III: 'fishing \& aquaculture' consisted of households who grow aquatic species besides fishing, and

- Group IV: 'fishing \& agriculture' consisted of households who cultivate agricultural produce besides fishing.

Initially, demographical characteristics were described to provide an overview of the study's participants. Then descriptive statistics of the impacts, responses, and income recovery of the Formosa incident on the four groups were figured out. At this point, an analysis of variance (ANOVA) followed by a Turkey method of multiple comparison post-hoc analysis (a Turkey method of multiple comparisons) was performed to examine the differences among the groups regarding their suffering, responding strategies, and restoration effectiveness from the incident. All the analyses were performed on STATA 15.0.

\section{Results}

\subsection{Descriptions of Participants}

Table 1 describes the demographic characteristics of participants in this study. Among the total of 301 surveyed households, 160 were selling fishing equipment, 88 were cultivating agricultural produce, and 31 were growing aquatic species, while only 22 households were keeping fishing as the only job.

Each household had around 4 to 5 people, of which three people were of working age. Regarding age, the average age of labor was from 39.9 to 47.1 years. There had been a wide variation in the wealth of households in the groups. Households in the 'fishing only' and 'fishing \& aquaculture' were the wealthiest, with the asset value per household around 1.5 billion VND. This figure was as twice the average asset value of a household in the 'fishing \& services' (619 million VND) and the 'fishing \& agriculture' (799 million VND). This difference was because the investment costs for offshore and near-shore fishing in boats or investment costs in shrimp ponds were remarkable. Regarding annual income, the 'fishing \& aquaculture' group had the highest income with an average of 941 million VND while the earnings of the remaining groups were only 301 ('fishing only'), 346 ('fishing \& services'), and 448 ('fishing \& agriculture') million VND per household.

Table 1. Demographic and socio-economic characteristics of the sampled households

\begin{tabular}{|c|c|c|c|c|c|}
\hline \multirow[b]{2}{*}{ Indicator } & \multirow[b]{2}{*}{ Unit } & \multicolumn{4}{|c|}{ Household group } \\
\hline & & $\begin{array}{c}\text { 'fishing } \\
\text { only' } \\
(\mathrm{n}=22)\end{array}$ & $\begin{array}{c}\text { 'fishing \& services' } \\
(\mathrm{n}=160)\end{array}$ & $\begin{array}{c}\text { 'fishing \& aquaculture' } \\
(\mathbf{n}=31)\end{array}$ & $\begin{array}{c}\text { 'fishing \& agriculture' } \\
(\mathbf{n}=\mathbf{8 8})\end{array}$ \\
\hline Household size & Person & 4 & 5 & 5 & 5 \\
\hline Number of labors & Person & 2 & 3 & 3 & 3 \\
\hline $\begin{array}{l}\text { Average Age of } \\
\text { labors }\end{array}$ & Years old & 47.1 & 39.9 & 40.1 & 40.2 \\
\hline $\begin{array}{l}\text { Number of } \\
\text { livelihoods }\end{array}$ & livelihood & 1.0 & 3.4 & 3.5 & 3.0 \\
\hline $\begin{array}{l}\text { Average Asset } \\
\text { value }\end{array}$ & $\begin{array}{c}\text { Million } \\
V N D\end{array}$ & 1,496 & 619 & 1,522 & 799 \\
\hline $\begin{array}{l}\text { Average Yearly } \\
\text { income }\end{array}$ & $\begin{array}{l}\text { Million } \\
V N D\end{array}$ & 301 & 346 & 941 & 448 \\
\hline
\end{tabular}




\subsection{Impacts of the Formosa Incident on Small-Scale Fishing Households}

The Formosa incident largely impacted three groups of households, including fishers, aquatic species growers, and fish vendors. The fish kill caused significant consequences for all households who had depended on marine-resource-based livelihoods. Thus, the majority of interviewed households experienced impacts on at least one livelihood activity related to marine resources. The incident affected both near-shore and offshore fishery activities. All fishery activities were completely stopped for at least six months in study sites (Table 2). Specifically, households of the 'fishing \& services' group were forced to stop their fishing for an average duration of 8.2 months. Interrupting periods of households in the 'fishing \& agriculture, the 'fishing \& aquaculture' and the 'fishing only' lasted 8.1 months, 6.4 months and 6.2 months, respectively.

Households suffered significant economic losses for prolonged periods which ex-post lost. Ex-post loss shows how income reduced when livelihood activities were halted, linked to market collapses and government regulations. Households in the 'fishing \& aquaculture' group experienced the highest income reduction with an average of 738.4 million VND per each. The reason was the considerable accumulated death of fish, shrimps, and other aquatic species in line with a large investment. 'Fishing \& services' and 'fishing \& agriculture' households faced lower loss (around 198 million VND per household) as they had less stored or contaminated seafood, as well as their livelihood, were less dependent on fishing than the other groups. A 'fishing only' household had an average loss of 239.7 million VND mainly came from an ex-post lost value which in part linked to a long period of reduced fishing intensity.

The proportion of economic loss in annual household income also significantly varied amongst the groups. The 'fishing only' households faced the highest lost proportion compared to their yearly income $(114.2 \%)$, which was much higher than that of 'fishing \& aquaculture' households $(99 \%)$ and the remained two groups $(80 \%$ 'fishing \& services' and 70\% - 'fishing \& agriculture'). Besides, surveyed households had a different perception of the severity of the Formosa incident on their livelihood. The majority of 'fishing \& aquaculture' households (83.9\%) said that the incident seriously impacted their livelihood. Similarly, nearly 6 out of 10 'fishing \& services' households have the same perception about the impact severity when 3 out of 10 households in this group said the incident seriously hit their livelihoods. In the other two groups, the severity was perceived as less severe. In the 'fishing \& agriculture' group, $51.1 \%$ of households indicated that impacts were very serious while $46.6 \%$ mentioned a serious level. Finally, only $31.8 \%$ of households in the 'fishing only' households perceived very serious impacts, while $68.2 \%$ indicated serious effects.

Table 2. Impacts of the Formosa incident to small-scale fishing households

\begin{tabular}{|c|c|c|c|c|c|}
\hline \multirow[b]{2}{*}{ Indicator } & \multirow[b]{2}{*}{ Unit } & \multicolumn{4}{|c|}{ Household group } \\
\hline & & 'fishing only' & $\begin{array}{l}\text { 'fishing \& } \\
\text { services' }\end{array}$ & $\begin{array}{c}\text { 'fishing \& } \\
\text { aquaculture' }\end{array}$ & $\begin{array}{r}\text { 'fishing \& } \\
\text { agriculture' }\end{array}$ \\
\hline Number of affected livelihoods & Livelihood & 1.0 & 2.1 & 2.5 & 1.4 \\
\hline $\begin{array}{l}\text { Stopped time of fishing activities due } \\
\text { to the incident }\end{array}$ & Month & 6.2 & 8.2 & 6.4 & 8.1 \\
\hline Economic loss caused by the incident & $\begin{array}{c}\text { Million } \\
\text { VND }\end{array}$ & 239.7 & 198.2 & 738.4 & 198.1 \\
\hline $\begin{array}{l}\text { Proportion of economic loss in annual } \\
\text { income }\end{array}$ & $\%$ & 114.2 & 80.7 & 99.0 & 70.9 \\
\hline Severity perception: 'very serious' & $\% h h s$ & 31.8 & 58.8 & 83.9 & 51.1 \\
\hline Severity perception: 'serious' & $\% h h s$ & 68.2 & 39.4 & 16.1 & 46.6 \\
\hline Severity perception: 'little' & $\%$ hhs & 0.0 & 1.8 & 0.0 & 2.3 \\
\hline
\end{tabular}




\subsection{Household Responses to the Formosa Incident}

Interviewed households mainly responded by coping and adaptation, and a few households resisted by transforming livelihood to cope with the Formosa incident (Table 3). As shown from table 3, a very high percentage of 'fishing only' households (81.8\%) coped with the incident by cutting spending, borrowing credit, receiving support from relatives, or/and engaging in new livelihood activities. The same thing happened to the 'fishing \& aquaculture', 'fishing \& agriculture' and 'fishing \& services' households with the responded proportion were $77.4 \%, 70.5 \%$ and $65 \%$, respectively. While adaptive responses are commonly found in the two above groups (64.5\% - 'fishing \& aquaculture'; $52.3 \%$ - 'fishing \& agriculture' and $45.6 \%$ 'fishing \& services') who adapted by making improvements in fishing and aquaculture methods in terms of improving techniques and production seasonal calendar, investing to buy new fishing gears or adjusting the menu in restaurants. Transformative responses were mostly implemented in the 'fishing \& services' and 'fishing \& agriculture' groups with $15 \%$ and $10.2 \%$ of households, respectively, when these small-scale households closed their business or stopped fishing to move to work as hired laborers or migrants.

The number of responses to the incidence impact varied by household groups. Households in the 'fishing \& services' and 'fishing \& aquaculture' groups were most prominent in applying responded solutions. Each household in the above two groups applied almost two livelihood strategies to cope or adapt to the environment shock while 'fishing only' and 'fishing \& agriculture' groups applied one livelihood strategy. Households in the study areas accessed the compensation from the government after the incident occurred. A 'fishing \& aquaculture' household had gotten 132.6 million VND on average, which was twice as much as that a 'fishing only' household had received. The compensated value of 'fishing only' households was much higher than those of 'fishing \& services' and 'fishing \& agriculture' households, about 1.5 times and 1.7 times, respectively.

According to interviewed-household perception, after 30 months since the Formosa incident, households in the study area were gradually recovering their incomes (Table 4). Most household perceptions indicated that their income was now fully or under recovered. It is the nearly four percent of households who were not able to recover that remains concerning.

Table 4 also shows that perception of 'fishing \& services', 'fishing \& aquaculture' and 'fishing \& agriculture' households had a relatively optimistic income restoration with above $60 \%$ households in each group believing that their income fully recovered. By contrast, most households in the 'fishing only' group (90.9\%) stated that their income had not fully recovered yet. More noticeable, it still witnessed a small percentage of households in the 'fishing $\&$ services' (3.8\%) and the 'fishing \& agriculture' (1.2\%) groups believed that their income would be impossible to be recovered because of the depletion of fishery resources after the environment incident.

Table 3. Household response and compensation to the incident impact

\begin{tabular}{cccccc}
\hline \multirow{2}{*}{ Types of response } & \multirow{2}{*}{ nit } & 'fishing only' & $\begin{array}{c}\text { 'fishing \& } \\
\text { services' }\end{array}$ & $\begin{array}{c}\text { 'fishing \& } \\
\text { aquaculture' }\end{array}$ & 'fishing \& agriculture' \\
\cline { 3 - 6 } & & 81.8 & 65.0 & 77.4 & 70.5 \\
Coping response & $\% h h s$ & 31.8 & 45.6 & 64.5 & 52.3 \\
Adaptation response & $\% h h s$ & 0.0 & 15.0 & 0.0 & 10.2 \\
Transform response & $\% h h s$ & 61.0 & 86.6 & 132.6 & 78.3 \\
Compensation & Million & $V N D$ & &
\end{tabular}

Table 4. Household income recovery 30 months post incident

\begin{tabular}{|c|c|c|c|c|c|}
\hline \multirow[b]{2}{*}{ Indicators } & \multirow[b]{2}{*}{ Unit } & \multicolumn{4}{|c|}{ Household group } \\
\hline & & 'fishing only' & $\begin{array}{l}\text { 'fishing \& } \\
\text { services' }\end{array}$ & $\begin{array}{c}\text { 'fishing \& } \\
\text { aquaculture' }\end{array}$ & 'fishing \& agriculture' \\
\hline Fully recovered & $\% h h s$ & 9.1 & 63.8 & 77.4 & 67.0 \\
\hline Under recovery & $\%$ hhs & 90.9 & 32.5 & 22.6 & 31.8 \\
\hline Impossible recover & $\% h h s$ & 0 & 3.8 & 0.0 & 1.2 \\
\hline
\end{tabular}


Table 5. Post-hoc analysis results

\begin{tabular}{|c|c|c|c|c|c|c|}
\hline \multirow{2}{*}{ Variable } & \multicolumn{6}{|c|}{ Group pair } \\
\hline & II vs I & III vs I & IV vs I & III vs II & IV vs II & IV vs III \\
\hline $\begin{array}{l}\text { Asset value } \\
(M . V N D / h h)\end{array}$ & Different & Not different & Different & Different & Not different & Different \\
\hline $\begin{array}{l}\text { Yearly income } \\
\text { before the } \\
\text { incident } \\
(M . V N D / h h)\end{array}$ & Not different & Different & Not different & Different & Not different & Different \\
\hline $\begin{array}{l}\text { Economic lost } \\
\text { value } \\
(M . V N D / h h)\end{array}$ & Not different & Different & Not different & Different & Not different & Different \\
\hline $\begin{array}{l}\text { Yearly income } \\
30 \text { years after the } \\
\text { incident } \\
(M . V N D / h h)\end{array}$ & Not different & Different & Not different & Different & Not different & Different \\
\hline $\begin{array}{c}\text { Perceived } \\
\text { recovery rate (\%) }\end{array}$ & Different & Different & Different & Not different & Different & Not different \\
\hline
\end{tabular}

\subsection{Livelihood Diversification and Resilience of Households}

The post-hoc analysis provides comparisons between pairs of household groups on the below variables. The analysis results were recorded in Table 5. It appears that the 'fishing \& aquaculture' group presented the most distinctive characteristics to the other groups while the differences between 'fishing \& services' and 'fishing \& agriculture' groups were modest.

With specific regards to recovery rate, it was revealed that the households in the 'fishing \& services' have been recovering faster than those in other groups. This group's index was significantly higher than that of 'fishing only' and 'fishing \& agriculture' and not significantly different from 'fishing \& aquaculture'. This superiority could be explained by three reasons. Firstly, households in the 'fishing \& services' group were the least dependent on fishery livelihoods as they have the smallest fishery asset value. Therefore, when the incident that mainly related to fishing industries occurred, their loss was the smallest. Secondly, households in this group were the most active ones adopting a transformation response as changing livelihood activities, although this was less common. Their existing great diversifications (more than two livelihood activities) allow them to implement a profound (or complete) change of livelihood, and this transformation is an effective mechanism for relieving the pain caused by the incident. Finally, these households also have the youngest labors who were biologically active. As a result, they introduced responses more proactively and effectively.

By contrast, the households in the 'fishing only' group have been recovering at the slowest speed. The recovery rate of 'fishing only" households is significantly lower than that of livelihood-diversified households. This might be accounted for the heavy dependence of income from fishing, inappropriate responses in spending and managing loans, and the limited human capital of these households. The reliance on just one source of income caused the households in 'fishing only' most severely hit by the incident as well as prevented them from quickly transforming into a new type of livelihood. Additionally, the fewness and agedness of these households significantly reduce their proactiveness and flexibility in handling environmental dynamics.

\section{Discussion and Conclusion}

Our research concluded that the perception of surveyed households on impact levels and capacity resilience are considered important aspects for impact assessment in the environmental shock context. Households have applied several livelihood solutions to cope with the impacts of environmental shock. In addition, the supporting from the government such as funds and subsidies also contribute to help local households to overcome impacts. The livelihood diversification of impacted households is significantly considered valuable in increasing the resilience process after the Ha Tinh Formosa incident. In which households have more diversified livelihood activities, the resilience is better. Based on the effort of households and support policies of the government, impacted households have gradually improved livelihood resilience.

This study supports previous study results and concludes that diversified livelihood is a good strategy to help fishing households reduce the impacts of environmental shocks and resource variation [23, 26, 29, 35-38]. Households who have fishing as the only livelihood activity suffered the highest percentage of loss in income. On the other hand, when households have two or three livelihood activities combined with fishery, such as providing services and agriculture production, the extent of the Formosa incident impacts their income was lessened. Despite facing a longer 
impact duration at more than eight months and owning lower asset values than the fishing \& aquaculture households, 'fishing \& services' and 'fishing \& agriculture' households had a smaller percentage of loss in income and their capacity to adapt and transform into other types of livelihoods is much higher compared to group I and III. This impact duration might be explained that it took six months for the government to test the water quality continuously and inform publicly that the water is safe for fishing. As a result, after six months, the fishermen were allowed to restart offshore fishing activities, but not near-shore fishing or demurral fishing. However, the impact for the 'fishing and services' group lasted longer when the market demand was decreased because consumers still did not believe in the quality of the sea fish at that time.

Moreover, among diversified groups, the 'fishing \& services' and 'fishing \& agriculture' groups were affected more heavily by the incident than 'fishing \& aquaculture' households. This is because these two former groups are the least dependent on fishery livelihoods, or the correlation between fishing as the main income source and other income sources is low. Thus, the risks are diversified, and as a result, they suffered the least from one shock.

In reality, having a wide range of investments or livelihoods with low correlation can be challenging for small-scale fishing households, given their constraints in resources and capacity, causing difficulties in mitigating the risks. The household's ability to recover also depends on the availability of other sources of income, including remittances from family members living outside the area, informal loans from money lenders or from the government, and systems of mutual support at the government and community level [51]. Therefore, the livelihood diversification of coastal livelihoods is not only about giving people jobs. It also requires addressing fundamental social, economic, and environmental reforms that affect coastal communities and livelihoods. Moreover, in some cases, livelihood diversification is effective only in the short term because of individual aspects such as occupation or individual social networks [52]. Therefore, in order to increase the resilience process, it needs to combine not only livelihood diversification but also the support from the government and expand the individual social networks through the transformative social learning process [53-55]. Our findings emphasize the need to have community-specific policies towards increasing resilience capacity. Environmental shocks might impact each household group in different ways, and their capacity to cope with these impacts is varies.

Extreme events are nothing new to the Central people in Vietnam, particularly related to climate. However, the environmental incidents were indeed new extreme events in this area [56]. Perception of impacted households and community to impact levels and understanding impacts of the anthropogenic marine environmental incidents have positively influenced the capacity and duration of resilience. Perception of impacted households and community to impact levels and understanding impacts of the anthropogenic marine environmental incidents have positively influenced the capacity and duration of recovery. We found that most of the four household groups are very aware of the impacts of the Formosa. Therefore, they already have and are most willing to invest in coping strategies as well as consensus with support and guideline to recovery livelihood and life from the central and local government. We found that most of the four household groups are very aware of the impacts of the Formosa, particularly group 3. Therefore, they have invested in coping strategies through livelihood diversification. In addition, most of households applied the guidelines of the government as well as local authorities in coping process. Based on the effort of each household and support policies of the government, impacted households have gradually resilient livelihood as well as their life.

\section{Acknowledgements}

This research is funded by Vietnam National Foundation for Science and Technology Development (NAFOSTED) under grant number 504.05-2018.05. Thanks also for Hue University for its partial support to this research.

\section{REFERENCES}

[1] Carter, M.R., et al., Shocks, sensitivity and resilience: Tracking the economic impacts of environmental disaster on assets in Ethiopia and Honduras. 2006.

[2] Lipschutz, R.D., Getting out of the CAR: decarbonisation, climate change and sustainable society. International Journal of Sustainable Society, 2012. 4(4): p. 336-356.

[3] Chau, M.N. and Y.-H. Sun, Fish Death Crisis Prompts Vietnam Waste Water Probe. 2016.

[4] National Steering Committee, Summary report of activities on solutions to stabilize life and production and business for people in 04 Central provinces affected by marine environmental incidents, M.o.A.a.R. Development, Editor. 2018, Ha Noi.

[5] Hoang, T., et al., Is Tomorrow Another Day? Coping with an Environmental Disaster: Evidence from Vietnam. 2018.

[6] Amer, R., China, Vietnam, and the South China Sea: disputes and dispute management. Ocean Development \& International Law, 2014. 45(1): p. 17-40.

[7] Oldekop, J.A., et al., Environmental impacts and scarcity perception influence local institutions in indigenous Amazonian Kichwa communities. Human Ecology, 2012. 40(1): p. 101-115.

[8] Somers, S., Measuring resilience potential: An adaptive strategy for organizational crisis planning. Journal of contingencies and crisis management, 2009. 17(1): p. $12-23$. 
[9] Gorenak, S. and V. Bobek, Total responsibility management indicators and sustainable development. International Journal of Sustainable Society, 2010. 2(3): p. 248-264.

[10] Allenby, B. and J. Roitz, Building the resilient firm: the new challenge to EHS organizations. Environmental Quality Management, 2005. 15(2): p. 27-36.

[11] Le, D.B.C., D.M.P. Le, and N.H. An, Labor migration - a livelihood strategy of rural households in the coastal areas of Quang Tri and Thua Thien Hue provinces.. Sustainable development, 2019. 9(3): p. 99-109.

[12] Rahut, D.B., et al., Rural Livelihood Diversification Strategies in Nepal. Poverty and Public Policy, 2014. 6(3).

[13] Nelson, K.H.a.J., Sustainable livelihood and livelihood diversification. IDS Working Paper 69, 1998.

[14] Sène-Harper, A.L., S.M. Camara, and D. Matarrita-Cascante, Does Diversification Lead to Livelihood Security in Fishing-Farming Communities? Insight from the Senegal River Delta. Human Ecology, 2019. 47(6): p. 797-809.

[15] Marschke, M.J. and F. Berkes, Exploring strategies that build livelihood resilience: a case from Cambodia. Ecology and Society, 2006. 11(1).

[16] Ellis, F., The Determinants of Rural Livelihood Diversification in Developing Countries. Agricultural Economics, 2000. 51(2): p. 289-302.

[17] Alobo Loison, S., Rural Livelihood Diversification in Sub-Saharan Africa: A Literature Review. The Journal of Development Studies, 2015. 51(9): p. 1125-1138.

[18] Rahut, D.B., and Maja, M. S.,, Livelihood diversification strategies in the Himalayas*. Australian Journal of Agricultural and Resource Economics, 2012. 56(4): p. 558-582.

[19] Ellis, F., Household strategies and rural livelihood diversification. Journal of Development Studies, 1998. 35(1): p. 1-38.

[20] Ifekwem, N. and O. Adedamola, Survival strategies and sustainability of small and medium enterprises in the Oshodi-Isolo Local Government Area of Lagos State. Acta Universitatis Sapientiae: Economics and Business, 2016. 4(1): p. 103-118.

[21] Béné, C., et al., Is resilience socially constructed? Empirical evidence from Fiji, Ghana, Sri Lanka, and vietnam. Global Environmental Change, 2016. 38: p. 153-170.

[22] Speranza, C.I., U. Wiesmann, and S. Rist, An indicator framework for assessing livelihood resilience in the context of social-ecological dynamics. Global Environmental Change, 2014. 28: p. 109-119.

[23] Torell, E., et al., Coastal livelihood diversification as a pathway out of poverty and vulnerability: Experiences from Tanzania. Coastal Management, 2017. 45(3): p. 199-218.

[24] Ayeb-Karlsson, S., et al., A people-centred perspective on climate change, environmental stress, and livelihood resilience in Bangladesh. Sustain Sci, 2016. 11(4): p. 679-694.

[25] Twigg, J., Disaster risk reduction. 2015: Overseas
Development Institute, Humanitarian Policy Group London.

[26] Gyawali, S., et al., Promoting sustainable livelihoods: An approach to postdisaster reconstruction. Sustainable Development, 2019.

[27] Ashley, C., Applying livelihood approaches to natural resource management initiatives: experiences in Namibia and Kenya. 2000: Overseas Development Institute London, UK.

[28] Twine, W., Multiple strategies for resilient livelihoods in communal areas of South Africa. African journal of range \& forage science, 2013. 30(1-2): p. 39-43.

[29] Asfaw, S., G. Pallante, and A. Palma, Diversification Strategies and Adaptation Deficit: Evidence from Rural Communities in Niger. World Development, 2018. 101: p. 219-234.

[30] Paavola, J., Livelihoods, vulnerability and adaptation to climate change in Morogoro, Tanzania. Environmental Science \& Policy, 2008. 11(7): p. 642-654.

[31] Twine, W., Multiple strategies for resilient livelihoods in communal areas of South Africa. Afr J Range Forage Sci, 2013. 30(1-2): p. 39-43.

[32] Besser, T.L., Resilient small rural towns and community shocks. Journal of Rural and Community Development, 2013. 8(1).

[33] Ahmed, M.T., et al., Diversification of rural livelihoods in Bangladesh. Journal of Agricultural Economics and Rural Development, 2015. 2(2): p. 32-38.

[34] Pain, A. and S. Levine, A conceptual analysis of livelihoods and resilience: addressing the'insecurity of agency'. 2012: ODI.

[35] Allison, E.H. and F. Ellis, The livelihoods approach and management of small-scale fisheries. Marine Policy, 2001. 25(2001).

[36] Finkbeiner, E.M., The role of diversification in dynamic small-scale fisheries: Lessons from Baja California Sur, Mexico. Global Environmental Change, 2015. 32: p. 139-152.

[37] Nayak, P.K., L.E. Oliveira, and F. Berkes, Resource degradation, marginalization, and poverty in small-scale fisheries: threats to social-ecological resilience in India and Brazil. Ecology and Society, 2014. 19(2).

[38] Ellis, F., Rural livelihood diversity in developing countries: evidence and policy implications. Vol. 40. 1999: Overseas Development Institute London.

[39] Kofinas, G.P. and F.S. Chapin, Sustaining livelihoods and human well-being during social-ecological change, in Principles of ecosystem stewardship. 2009, Springer. p. $55-75$.

[40] FAO, World review of fisheries and aquaculture. 2008.

[41] Ministry of Agriculture \& Rural Development, The overview of Vietnam seafood industry. 2019, Vietnam Association of Seafood Exporters and Producers: Ha Noi.

[42] Hallegatte, S., M. Fay, and E.B. Barbier, Poverty and 
climate change: introduction. Environment and Development Economics, 2018. 23(3): p. 217-233.

[43] Minh, H.B., Vietnam, grappling with mass fish deaths, clamps down on seafood sales. 2016.

[44] Pham, D. and M.N. Chau, Beaches of Dead Fish Test New Vietnam Government's Response. 2016.

[45] Mullman, S., A Taiwanese Steel Plant Caused Vietnam's Mass Fish Deaths the Government Says. 2016.

[46] Ya-chen, T., F. Ching-i, and E. Hsu, Taiwanese Safe Amid Protest at Formosa Plastics' Vietnam plant. Focus Taiwan, 2016.

[47] Van Truong, T., et al., Household recovery from disaster: insights from Vietnam's fish kill. Environmental Hazards, 2021: p. 1-16.

[48] Vietnam Ministry of Finance, Report on budget and expenditure for compensation and support in response to the affects of the marine environmental incident, 2016. Hanoi, Vietnam. 2018.

[49] Thua Thien Hue CPC, Summary report on compensation and support due to marine environmental incidents in Thua Thien Hue. DONRE. 2018.

[50] Chambers, R., Participatory rural appraisal (PRA): Analysis of experience. World development, 1994. 22(9): p. 1253-1268.

[51] Pomeroy, R.S., et al., Coping with disaster: rehabilitating coastal livelihoods and communities. Marine Policy, 2006. 30(6): p. 786-793.
[52] Armah, F.A., et al., Impact of floods on livelihoods and vulnerability of natural resource dependent communities in Northern Ghana. Water, 2010. 2(2): p. 120-139.

[53] Phuong, L.T.H., et al., Increasing Vietnamese smallholder farmers' adaptive capacity to respond to climate change. Local Environment, 2018. 23(8): p. 879-897.

[54] Tarnoczi, T., Transformative learning and adaptation to climate change in the Canadian Prairie agro-ecosystem. Mitigation and Adaptation Strategies for Global Change, 2011. 16(4): p. 387-406.

[55] Wals, A.E. and F. Heymann, Learning on the Edge: Exploring the change potential of conflict in social learning for sustainable living, in Educating for a culture of social and ecological peace, A.L. Wenden, Editor. 2004, State University of New Your Press: New York. p. 123.

[56] Sơn, Đ.N. and N.V. Tuân, Solutions to restore livelihoods of near-shore fishing people affected by the 2016 marine environmental incident in the Central region: A case study in Phu Dien commune, Phu Vang district, Thua Thien Hue province. Journal of Science and Agricultral technology, 2019. 3(1): p. 1147-1154.

[57] Reidsma, P., et al., Adaptation to climate change and climate variability in European agriculture: the importance of farm level responses. European journal of agronomy, 2010. 32(1): p. 91-102.

[58] Renko, M., R.C. Shrader, and M. Simon, Perception of entrepreneurial opportunity: a general framework. Management Decision, 2012. 50(7): p. 1233-1251 